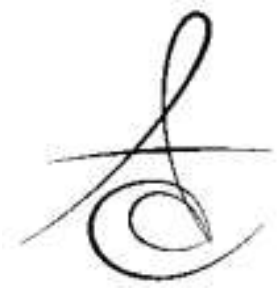

\title{
YAZILI VE GÖRSEL MEDYADA FLOR HAKKINDA YAYINLANAN HABERLERİN HASTA EBEVEYNLERİ ÜZERİNE ETKİSİ
}

\section{INFLUENCE OF PUBLISHED NEWS ABOUT FLUORIDE IN WRITTEN AND VISUAL MEDIA ON PATIENT'S PARENTS}

\author{
Dr.Dt. Yasemin GÜLER* \\ Doç.Dr. Sera ŞİMŞEK DERELIOĞLU*
}

Makale Kodu/Article code: 3855

Makale Gönderilme tarihi: 17.10 .2018

Yasemin Güler: ORCID ID: $0000-0003-4544-7079$

Kabul Tarihi: 18.12.2018

Sera Şimşek Derelioğlu: ORCID ID: 0000-0001-5192-923X

DOI : $10.17567 /$ ataunidfd.498737

\section{öz}

Amaç: Bu çalışmanın amacı; yazılı ve görsel medyada flor hakkında yayınlanan haberlerin hasta ebeveynleri üzerine etkisinin değerlendirilmesidir.

Materyal ve Metod: Çalışma Atatürk Üniversitesi Diş Hekimliği Fakültesi Pedodonti Anabilim Dalına başvuran 50 çocuk hastanın ebeveyni (26 kadın, 24 erkek) ile gerçekleştirilmiştir. Çalışma anket çalışması şeklinde planlanmış olup, ilk bölümde katıııcıların demografik verileri kaydedilmiş, ikinci bölümde ise flor ile ilgili sorular (diş macunu içeriği, flor kullanım amaçları, yan etkileri, koruyucu flor uygulamaları vb.) yöneltilmiștir. İkinci bölümde ayrıca flor hakkında edindikleri bilgilerin kaynağına yönelik sorularla, yazılı ve görsel medyayı kullanım sıkıkları hakkında sorular da bulunmaktadır. Anket sorularının ardından flor hakkında doğru bilgiler içeren bir sunum yapılmıștır. Sunumdan iki ay sonra katılımcılar tekrar davet edilerek bir son test yapılmış ve bilgilendirme sonrası fikirlerinin ne yönde değiştiği belirlenmiştir. Elde edilen veriler ise SPSS 20.0 programında istatistiksel olarak değerlendirilmiștir.

Bulgular: Anket sorularına verilen cevaplara bakıldığında \%48 çoğunlukla günlük 1-3 saatlerini haberleşme ve iletişim araçlarına ayırdıkları, güncel konular hakkındaki bilgileri \%24 çoğunlukla internet (sosyal medyadan) elde ettikleri, haberleșme ve iletişim araçlarını \%35 çoğunlukla kısmen güvenilir buldukları tespit edilmiştir. Bilgilendirme sunumundan önce ve sonra, flor ve diş macunu ile ilgili sorulara verilen cevapların yüzdelikleri karşılaştırıldığında doğru cevapların yüzdesinin arttığı gözlemlenmiş̧ir.

Sonuç: Çalışmamızdan elde edilen veriler ıșığında, kișilerin medyada yayımlanan yanlış/eksik bilgi içerikli sağlık haberlerinden olumsuz yönde etkilenebileceği, bu sebeple hasta ve hasta yakınlarının güncel sağlık konularında uzman hekimler tarafından daha çok bilgilendirilmesinin gerekliliği ortaya konulmuştur.

Anahtar Kelimeler: Flor, medyadaki flor haberleri, anket çalışması

\section{ABSTRACT}

Aim: The aim of this study is; the evaluation of the effect of the news about the fluoride in written and visual media on the patient's parents.

Materials and Methods: The study consisted of 50 child patients's parents ( 26 female, 24 male) who applied to Atatürk University, Faculty of Dentistry, Department of Pediatric Dentistry. The study was planned in the form of a questionnaire, in which the demographic data of the participants were recorded in the first part and the questions related to fluoride (toothpaste contents, fluoride use purposes, side effects, protective fluoride applications, etc.) were directed. In the second part, there are also questions about the sources of information about flüoride and the frequency of use of written and visual media. Following the questionnaire, a presentation with the correct information about flüoride was made. Two months after the presentation, the participants were invited again and a final test was carried out to determine the change in their post-informed opinion. The obtained data were evaluated statistically in SPSS 20.0 program.

Result: When the answers to the questionnaire were examined, it was found that they share 1-3 hours daily communication and communication tools, mostly about $24 \%$ of the information about current topics, mostly internet (social media), communication and communication tools mostly $35 \%$ reliable. When the percentages of there sponses to the questions about flüoride and toothpaste were compared before and after informative presentation, it was observed that the percentage of correct answers increased.

Conclusion: In our study, it has been suggested that people should be informed more about the current health issues as the specialist physicians, because the health news of the people with wrong / incomplete information published in the media may be affected negatively.

Keywords: Fluoride, fluoride news in the media, survey study

\footnotetext{
*Atatürk Üniversitesi, Diş Hekimliği Fakültesi, Pedodonti Anabilim Dalı, Erzurum, Türkiye

Kaynakça Bilgisi: Güler Y, Şimşek Derelioğlu Ş.Yazılı ve Görsel Medyada Flor Hakkında Yayınlanan Haberlerin Hasta Ebeveynleri Üzerine Etkisi. Atatürk Üniv Diş Hek Fak Derg 2020; 30: 41-47.

Citation Information: Guler Y, Simsek Derelioglu Ş. Influence of Published News About Fluoride in Written and Visual Media on Patient's Parents. J Dent Fac Atatürk Uni 2020: 30: 41-47.
} 


\section{GİRİŞ}

Çağımızda teknolojinin gelişmesiyle birlikte yaşanılan en büyük değişimlerden birisi iletişim alanında kendini göstermektedir. İletişim alanında medya, ulusal ve uluslararası düzeyde bireylere ulaşma konusunda önemli bir görev üstlenmektedir. ${ }^{1}$

Aynı zamanda medya (yazılı basın, radyo, televizyon, internet vb. gibi), özellikle toplumsal hayatta bireylerin çeşitli sosyal intiyaçlarını gidermek için sık sık kullandığı kaynakların başında gelmektedir. Sosyal toplumlarda bireyler bu kaynağı bilgi edinme, haber alma, eğlenme, sosyalleşme gibi amaçlarla kullanmaktadır. Medya topluma ve dolayısıyla bireylere bu çerçevede sorumluluklarını yerine getirmelidir. Bu sorumluluklar arasında doğru ve tarafsız olarak bilgilendirme, eğitimi destekleyen yayınlar, eğlendirici yayınlar ve sosyalleştirme içerikli programlar vb. yer alabilir. $^{2}$

Sosyoekonomik durumu düşük olan bireyler üzerinde medyanın etkisi oldukça büyüktür. ${ }^{3}$ Çünkü bireyler çağımızda medya sayesinde istedikleri bilgiye çaba harcamadan ulaşabilir konumdadır. Bilgiye ulaşma kolaylığı, medyanın insanları etkileme gücüyle birleşince de doğru ya da yanlış herhangi bir bilginin bireyler arasında hızla yayılması oldukça kolay hale gelmiştir. Yapılan yayınların yeterince kontrollü olamaması bireylerin dolayısıyla toplumun yanlış ya da eksik bilgilenmesine sebep olmaktadır. Bu bilgi kirliliği özelikle sağlık gibi önemli konularda olunca durumun ciddiyeti daha da artmaktadır. Bireyler medyaya duydukları güvenle, sorgulama ihtiyacı duymadan edindikleri bilgiler ışığında sağlıklarıyla ilgili yanlış kararlar verebilmektedir. ${ }^{4}$

Tüm alanlarda olduğu gibi sağlık alanlarında da yanlış ve eksik bilgilendirme olabilmektedir. Son zamanlarda, Türkiye' de medyada çıkan bazı haberlerle flor hakkında, diş macunlarındaki florun otizme veya zeka geriliğine neden olduğu gibi yanlış görüşlere yer verilmiştir. Bu bilgi kaynağı içme sularında kabul edilen optimum seviyeden çok daha yüksek seviyelerde flor bulunan Çin, Moğolistan ve İran gibi ülkelerde endemik florozisin bulunduğu bölgelerde yapılmış IQ seviyesi üzerinde yüksek doz florun etkisinin araştırıldığı çalışmalardır. ${ }^{5-10}$

Bu çalışmalar aynı zamanda sosyoekonomik düzeyi düşük bölgelerde yapılmış çalışmalardır. Annenin hamileliği süresince beslenmesi, ebeveynlerin eğitim seviyesi ve çocuğun beslenme şeklinin IQ seviyesinin gelişiminde önemli yer tuttuğu bilinmektedir. ${ }^{6}$ Yüksek flor maruziyetine bağlı kronik flor toksisitesinin uzun süreli olduğu durumlarda, nöronal ve serebrovasküler bütünlük bozulmakta, anormal davranış paternleri açığa çıkmakta ve beyinde metabolik lezyonlar meydana getirdiği bilinmektedir. ${ }^{11}$ Fakat bu yüksek doza düzenli florlu diş macunu kullanarak ulaşmak söz konusu değildir.

Basında yer alan bu bilgiler bir uzman tarafından verilmediği için toplumun yanlış bilgilendirilmesine neden olmuştur. Bu sebeple, Türk Dişhekimleri Birliği ve Türk Pedodonti Derneği, bilimsel kanıtlara dayanmayan açıklamalardaki yanlışları ortaya çıkaran ortak bir rapor sunmuşlardır. ${ }^{12}$ Raporda, dişlerin sağlığının ağız içerisindeki ekolojik ortamda bulunan dinamik dengeye bağlı olduğu, ağız boşluğunda bulunan bakteriler ile şekerin, bu dengeyi olumsuz yönde etkilediği belirtilirken, tükürük ve florun dişlerin sağlam kalmasında olumlu etkisi olduğunun da bilimsel olarak kanıtlandığı ifade edilmiştir. Ayrıca diş çürüklerinin kontrolü ve engellenmesi için florun kullanımı diş hekimliği alanında uzun yıllardır güvenli ve etkili bir yöntem olma özelliğini sürdürdüğü, özellikle macun gibi topikal uygulamalar ile daha fazla yarar sağlandığını belirtmişlerdir. Topikal flor uygulamaları diş çürüklerini önlemede oldukça etkilidirler ve flor içeren diş macunları dünya genelinde kullanılmaktadır. ${ }^{13,14}$

Dünya Sağlık Örgütü (WHO), Dünya Diş Hekimleri Birliği (FDI), Avrupa Pediatrik Diş Hekimliği Birliği (EAPD) ve Amerikan Pediatrik Diş Hekimliği Birliği (AAPD), toplumsal bir sağlık problemi olan diş çürüğünün azaltılmasında, içme sularının florlanması da dahil olmak üzere çeşitli yöntemlerle flor uygulamalarının etkili olduğunu bilimsel raporlarla açıklamışlardır. ${ }^{15-18}$ Yine bu birlikler, diş hekiminin önerdiği miktarda, günde 2 kere florlu diş macunu ile dişlerin fırçalanmasının çürüğün azaltılmasında önemli rol oynadığını ve yüksek çürük riskli bireylerde diş hekimi tarafından uygulanan flor uygulamalarının da çürük oluşumunu engellemede önerildiğini belirtmişlerdir. ${ }^{19}$

Son zamanlarda flor ile ilgili medyada yayınlanan haberlerin fakültemize başvuran hasta ebeveynlerinin olumsuz etkilendiğinin fark edilmesi üzerine planlamış olduğumuz bu çalışmada, bu etkilenmenin derecesi, hasta ebeveynlerinin flor konusundaki fikirleri, bilgileri ve flor hakkında medyanın insanları etkileme gücünün araştırılması amaçlanmıştır. 


\section{MATERYAL VE METOD}

Çalışma için Atatürk Üniversitesi Etik Kurulu Başkanlığından 11.01.2018 tarihinde 08 sayılı etik kurul onayı alınmıştır. Çalışmamıza, Atatürk Üniversitesi Diş Hekimliği Fakültesi Pedodonti Anabilim Dalına 15.01.2018/ 15.02.2018 tarihleri arasında çocuğunun tedavi randevusu için başvuran, Erzurum ve çevresinde yaşayan 26 kadın, 24 erkek olmak üzere 50 hasta ebeveyni katılmıştır. Hasta ebeveynlerine yapacağımız çalışma detaylıca anlatılmış olup, hasta onam formu imzalatılmıştır. Katılımcıların demografik özellikleri (cinsiyet, eğitim durumu, yaş aralığı, meslek ve gelir seviyesi) hazırlanan forma kaydedilmiştir.

Hasta ebeveynlerine diş macunu içeriği, flor kullanım amaçları, yan etkileri, koruyucu flor uygulamaları ve benzeri konular üzerine soru yöneltilmiş olup aynı zamanda bu bilgilerin kaynağı hakkında sorular içeren anket dağıtılmış ve anket sorularını kendilerine en yakın gelen cevabı işaretleyerek cevaplamaları istenmiştir. Ardından sözlü ve görsel bir sunum (oral hijyen ve koruyucu diş hekimliği konulu) ile hasta ebeveynlerine konu hakkında doğru bilgilendirme yapılmıştır. Sunumun ardından 2 (iki) ay sonra hasta ebeveynleri tekrar çağırılarak, aynı anket sorularını bir kez daha cevaplamaları istenmiştir.

\section{Istatistiksel Değerlendirmeler}

Elde edilen veriler ise SPSS 20.0 programında istatistiksel olarak değerlendirilmiştir. Verilerin değerlendirmesinde ise tanımlayıcı istatistikler (ortalama, yüzde değerleri) kullanılmıştır.

\section{BULGULAR}

Çalışmamıza 26 kadın, 24 erkek olmak üzere 50 hasta ebeveyni katılmıştır. Anket sorularına verilen cevaplar incelendiğinde anket güvenirliği 0,437 ile orta güvenirlik seviyesindedir.

Katılımcıların demografik bilgileri Tablo 1'de verilmiştir.

Ankete katılanların cinsiyet bilgilerine bakıldığında, araştırma örnekleminin cinsiyet bakımından hemen hemen eşit bir dağılım gösterdiği görülmektedir (Tablo 1). Yerleşim yerine göre bakıldığında katılımcıların \%80'inin şehirde yaşadığı gözlemlenmektedir.

Ankete katılanların yaş bilgileri değerlendirildiğinde ankete katılan katılımcıların \%74'ü 30-50 yaş aralığındadır. Katılımcıların eğitim durumlarını gösteren demografik veriler incelendiğinde, araştırmada elde edilen örneklemin eğitim seviyesinin lise ve üstü eğitime sahip olanlar \%74'lük bir dilimi oluşturmaktadır. Meslek durumu ve gelir düzeyi incelendiğinde katılımcıların \%48'i kamu çalışanı olup orta gelir düzeyine sahiptir.

Tablo1. Katılımcıların Demografik Verileri

\begin{tabular}{|c|c|}
\hline \multicolumn{2}{|c|}{ Katılımcıların cinsiyete göre sayıları ve yüzdeleri } \\
\hline CİNSİYET & n (\%) \\
\hline KADIN & $26(\% 52)$ \\
\hline ERKEK & $24(\% 48)$ \\
\hline Toplam & $50(\% 100)$ \\
\hline \multicolumn{2}{|c|}{ Katılımcıların yaşadığı yerlere göre sayıları ve yüzdeleri } \\
\hline YERLEŞİM & n (\%) \\
\hline KENTSEL YERLEŞİM & $41(\% 82)$ \\
\hline KIRSAL YERLEŞİM & $8(\% 18)$ \\
\hline Toplam & $50(\% 100)$ \\
\hline \multicolumn{2}{|c|}{ Katılımcıların yaş aralıkları } \\
\hline YAŞ ARALIĞI & n (\%) \\
\hline $20-29$ yaş & $8(\% 16)$ \\
\hline 30-39 yaş & $19(\% 38)$ \\
\hline $40-49$ yaş & $18(\% 36)$ \\
\hline $50-59$ yaş & $2(\% 4)$ \\
\hline 60 yaş üstü & $3(\% 6)$ \\
\hline Toplam & $50(\% 100)$ \\
\hline \multicolumn{2}{|c|}{ Katılımcıların eğitim durumları } \\
\hline EĞİTİM DURUMU & n (\%) \\
\hline Okuryazar değil & $1(\% 2)$ \\
\hline İlköğretim & $12(\% 24)$ \\
\hline Lise & $17(\% 34)$ \\
\hline Üniversite & $16(\% 32)$ \\
\hline Yüksek lisans & $4(\% 8)$ \\
\hline Toplam & $50(\% 100)$ \\
\hline \multicolumn{2}{|c|}{ Katılımcıların mesleki durumları } \\
\hline MESLEK & n (\%) \\
\hline Çalışmıyor & $14(\% 28)$ \\
\hline Serbest meslek & $8(\% 16)$ \\
\hline Özel sektör & $4(\% 8)$ \\
\hline Kamu personeli & $24(\% 48)$ \\
\hline Toplam & $50(\% 100)$ \\
\hline \multicolumn{2}{|c|}{ Katılımcıların gelir seviyeleri } \\
\hline GELİR SEVİYESİ & n (\%) \\
\hline Düşük & $13(\% 26)$ \\
\hline Orta & $24(\% 48)$ \\
\hline Yüksek & $13(\% 26)$ \\
\hline Toplam & $50(\% 100)$ \\
\hline
\end{tabular}

Katılımcılara yönelttiğimiz iletişim araçlarına yönelik sorulara verdikleri cevaplara ait veriler Tablo 212 arasında görülmektedir. Yapılan istatistiksel analizde kadın ve erkek ebeveynler arasında yöneltilen sorulara göre anlamlı bir farklılık bulunmadığı için, elde ettiğimiz veriler yüzde değerler olarak sunulmuştur.

"Günlük ne kadar bir süreyi haberleşmeiletişim araçlarına [gazete, televizyon, internet (sosyal medya)] ayırmaktasınız?" sorusuna verilen yanıtlara bakıldığında cinsiyete göre dağılım Tablo 2'de verilmiştir. Bireylerin \%48'inin 1-3 saatlik vakitlerini iletişim araçlarına ayırdıkları gözlemlenmiştir. 
Tablo 2. "Günlük ne kadarlık bir süreyi haberleşme-iletişim araçlarına [gazete, televizyon, internet (sosyal medya)] ayırmaktasınız?"sorusuna verilen cevapların yüzde dağıım

\begin{tabular}{|c|c|c|c|}
\hline & Kadın & Erkek & Toplam \\
\hline 30 dk-1saat & $8(\% 30,8)$ & $5(\% 20,8)$ & $13(\% 26)$ \\
\hline 1-3 saat & $13(\% 50)$ & $11(\% 45,8)$ & $24(\% 48)$ \\
\hline 3-5 saat & $3(\% 11,5)$ & $6(\% 25)$ & $9(\% 18)$ \\
\hline 5-7 saat & $2(\% 7,6)$ & $2(\% 8,3)$ & $4(\% 8)$ \\
\hline Toplam & $26(\% 100)$ & $24(\% 100)$ & $50(\% 100)$ \\
\hline
\end{tabular}

"Güncel konular hakkındaki bilgileri hangi kaynaktan elde ediyorsunuz?" sorusuna verilen yanıtların cinsiyete göre dağılımı Tablo 3'te verilmiştir.

"Haberleşme ve iletişim araçlarından elde ettiğiniz bilgilerin güvenirliği konusunda ne düşünüyorsunuz?" sorusuna verilen cevapların cinsiyete göre dağılımı Tablo 4' te verilmiştir.

"Güncel sağlık konuları hakkındaki bu bilgilerı nereden edindiniz?" sorusuna verilen yanitlara bakıldığında elde edilen cevapların dağılımı Tablo 5'te verilmiştir.

"Medyadaki verilen mesajlardan ne kadar etkilenirsiniz?" sorusuna verilen yanıtların dağılımı Tablo 6'da verilmiştir.

Tablo 3. "Güncel konular hakkındaki bilgileri hangi kaynaktan elde ediyorsunuz?"sorusuna verilen cevapların yüzde dağılımı

\begin{tabular}{|l|c|c|c|}
\hline & Kadın & Erkek & Toplam \\
\hline $\begin{array}{l}\text { Konuyla ilgili } \\
\text { uzman kişilerden }\end{array}$ & $2(\% 7,7)$ & $1(\% 4,2)$ & $3(\% 6)$ \\
\hline Gazete & $0(\% 0,0)$ & $2(\% 8,3)$ & $2(\% 4)$ \\
\hline Televizyon & $10(\% 38,5)$ & $11(\% 45,8)$ & $21(\% 42)$ \\
\hline $\begin{array}{l}\text { İnternet } \\
\text { (sosyal medya) }\end{array}$ & $14(\% 53,8)$ & $10(\% 41,7)$ & $24(\% 48)$ \\
\hline Toplam & $26(\% 100)$ & $24(\% 100)$ & $50(\% 100)$ \\
\hline
\end{tabular}

Tablo 4. "Haberleşme ve iletişim araçlarından elde ettiğiniz bilgilerin güvenirliği konusunda ne düşünüyorsunuz?" sorusuna verilen cevapların cinsiyete göre yüzde dağıımı

\begin{tabular}{|l|c|c|c|}
\hline & Kadın & Erkek & Toplam \\
\hline $\begin{array}{l}\text { Kesinlikle güvenilir } \\
\text { bulmuyorum. }\end{array}$ & $1(\% 3,8)$ & $2(\% 8,3)$ & $3(\% 6)$ \\
\hline $\begin{array}{l}\text { Kısmen güvenilir } \\
\text { buluyorum. }\end{array}$ & $18(\% 69,2)$ & $17(\% 70,8)$ & $35(\% 70)$ \\
\hline $\begin{array}{l}\text { Çoğunlukla güvenilir } \\
\text { buluyorum. }\end{array}$ & $4(\% 15,4)$ & $5(\% 20,8)$ & $9(\% 18)$ \\
\hline $\begin{array}{l}\text { Kesinlikle güvenilir } \\
\text { buluyorum. }\end{array}$ & $3(\% 11,5)$ & $0(\% 0,0)$ & $3(\% 6)$ \\
\hline Toplam & $26(\% 100)$ & $24(\% 100)$ & $50(\% 100)$ \\
\hline
\end{tabular}

Tablo 5. "Güncel sağlık konuları hakkındaki bu bilgileri nereden edindiniz?"sorusuna verilen yanıtların yüzde dağılımı

\begin{tabular}{|l|c|}
\hline & $\mathbf{n}(\%)$ \\
\hline Konuyla ilgili uzman kişilerden & $17(\% 34)$ \\
\hline Gazete & $1(\% 2)$ \\
\hline Televizyon & $16(\% 32)$ \\
\hline Internet (sosyal medya) & $16(\% 32)$ \\
\hline Toplam & $50(\% 100)$ \\
\hline
\end{tabular}

"Kullandığınız diş macunlarının içeriğine ne kadar dikkat edersiniz?" sorusuna ilk anket ve bilgilendirme sonrasında yapılan ikinci ankette verilen cevaplar Tablo 7'de verilmiştir. İlk anket ve bilgilendirme sonrasında yapılan ikinci anket cevapları karşılaştırıdığında ise; ilk ankette bu soruya "Kesinlikle dikkat ederim" cevabı \%22 oranında işaretlenmiş iken, aynı soruya bilgilendirme sunumundan sonra katılımcılar \%58 oranında bu cevabını vermişlerdir.

Tablo 6. "Medyadaki verilen mesajlardan ne kadar etkilenirsiniz?"sorusuna verilen yanıtların yüzde dağılımı

\begin{tabular}{|l|c|}
\hline & $\mathbf{n}(\%)$ \\
\hline Hiç etkilenmem. & $3(\% 6)$ \\
\hline Kısmen etkilenirim. & $31(\% 62)$ \\
\hline Etkilenirim. & $15(\% 30)$ \\
\hline Çok etkilenirim. & $1(\% 2)$ \\
\hline Toplam & $50(\% 100)$ \\
\hline
\end{tabular}

Tablo 7. " Kullandığınız diş macunlarının içeriğine ne kadar dikkat edersiniz ?" sorusuna verilen cevapların yüzde dağılımı

\begin{tabular}{|l|c|c|}
\hline & $\begin{array}{c}\text { Anket I } \\
(\mathbf{n}, \%)\end{array}$ & $\begin{array}{c}\text { Anket II } \\
(\mathbf{n}, \%)\end{array}$ \\
\hline Kesinlikle dikkat ederim. & $11(\%$ 22) & $29(\%$ 58) \\
\hline $\begin{array}{l}\text { Çoğunlukla dikkat } \\
\text { ederim. }\end{array}$ & $14(\% 28)$ & $15(\% 30)$ \\
\hline Kısmen dikkat ederim. & $20(\% 40)$ & $4(\% 8)$ \\
\hline Hiç dikkat etmem. & $5(\% 10)$ & $2(\% 4)$ \\
\hline Toplam & $50(\% 100)$ & $50(\% 100)$ \\
\hline
\end{tabular}

"Kullandığınız diş macunlarının içerisindeki flor miktarına ne kadar dikkat edersiniz?" sorusuna verilen cevapların yüzde oranları Tablo 8'de gösterilmiştir. İlk anket ve bilgilendirme sonrasında yapılan ikinci anket cevapları karşılaştırıldığında ise; ilk ankette bu soruya "Kesinlikle dikkat ederim." cevabı \%12 oranında işaretlenmiş iken, aynı soruya bilgilendirme sunumundan sonra katılımcilar \%44 oranında bu cevabı vermişlerdir.

"Florun diş çürümelerini önlemek, var olan diş çürüklerinin ise ilerlemesini durdurmak için diş macunlarına eklendiği konusunda ne düşünüyorsunuz?" sorusuna verilen cevapların yüzde dağılımı Tablo 9'da 
gösterilmiştir. İlk anket ve bilgilendirme sonrasında yapılan ikinci anket cevapları karşılaştırıldığında ise; ilk ankette bu soruya "Kesinlikle doğru buluyorum." cevabı \%26 oranında işaretlenmiş iken, aynı soruya bilgilendirme sunumundan sonra katılımclar \% 66 oranında bu cevabı vermişlerdir.

Tablo 8. "Kullandığınız diş macunlarının içerisindeki flor miktarına ne kadar dikkat edersiniz?" sorusuna verilen cevapların yüzde dağılımı

\begin{tabular}{|l|c|c|}
\hline & $\begin{array}{c}\text { Anket I } \\
(\mathbf{n}, \%)\end{array}$ & $\begin{array}{c}\text { Anket II } \\
(\mathbf{n}, \%)\end{array}$ \\
\hline Kesinlikle dikkat ederim. & $6(\% 12)$ & $22(\% 44)$ \\
\hline Çoğunlukla dikkat ederim. & $18(\% 36)$ & $15(\% 30)$ \\
\hline Kısmen dikkat ederim. & $15(\% 30)$ & $8(\% 16)$ \\
\hline Hiç dikkat etmem. & $11(\% 22)$ & $5(\% 10)$ \\
\hline Toplam & $50(\% 100)$ & $50(\% 100)$ \\
\hline
\end{tabular}

"Florun diş çürümelerini önlemek, var olan diş çürüklerinin ise ilerlemesini durdurmak için koruyucu diş tedavisi olarak diş hekimi tarafindan çocuklarınızın dişlerine uygulanması konusunda ne düşünüyorsunuz?" sorusuna verilen yanıtların yüzde dağılımı Tablo 10'da verilmiştir. İlk anket ve bilgilendirme sonrasında yapılan ikinci anket cevapları karşılaştırıldığında ise; ilk ankette bu soruya "Diş hekimi uygun görüyorsa kesinlikle uygulanabilir." cevabı \%74 oranında işaretlenmiş iken, aynı soruya bilgilendirme sunumundan sonra katılımcılar \%88 oranında bu cevabı vermişlerdir.

"Flor içeren diş macunlarının zeka geriliği veya otizme sebep olduğu konusundaki düşüncelere katılıyor musunuz?" sorusuna verilen yanıtların yüzde dağılımı Tablo 11 'de verilmiştir. İlk ve bilgilendirme sonrasında yapılan ikinci anket cevapları karşılaştırıldığında ise; ilk ankette bu soruya "Kesinlikle katılmıyorum." cevabı \%38 oranında işaretlenmiş iken, aynı soruya bilgilendirme sunumundan sonra katılımcllar $\% 66$ oranında bu cevabı vermişlerdir.

"Diş macunlarının tüplerinin dip kısmında bulunan renklerin diş macunlarının kimyasal içeriği hakkında bilgi verdiği konusundaki düşüncelere katılıyor musunuz?" sorusuna verilen yanıtların yüzde dağılımı Tablo 12' de verilmiştir. İlk anket ve bilgilendirme sonrasında yapılan ikinci anket cevapları karşılaştırıldığında ise; ilk ankette bu soruya "Kesinlikle katılmıyorum." cevabı \%12 oranında işaretlenmiş iken, aynı soruya bilgilendirme sunumundan sonra katılımcılar \%64 oranında bu cevabı vermişlerdir.
Tablo 9. "Florun diş çürümelerini önlemek, var olan diş çürüklerinin ise ilerlemesini durdurmak için diş macunlarına eklendiği konusunda ne düşünüyorsunuz?" sorusuna verilen cevapların yüzde dağııımı

\begin{tabular}{|l|c|c|}
\hline & $\begin{array}{c}\text { Anket I } \\
(\mathbf{n}, \%)\end{array}$ & $\begin{array}{c}\text { Anket II } \\
(\mathbf{n}, \%)\end{array}$ \\
\hline Kesinlikle doğru buluyorum. & $13(\% 26)$ & $33(\% 66)$ \\
\hline $\begin{array}{l}\text { Bu bilgini kısmen doğru } \\
\text { olacağını düşünüyorum. }\end{array}$ & $28(\% 56)$ & $7(\% 14)$ \\
\hline $\begin{array}{l}\text { Bu bilginin doğruluğu } \\
\text { hakkında şüpheliyim. }\end{array}$ & $7(\% 14)$ & $8(\% 16)$ \\
\hline $\begin{array}{l}\text { Kesinlikle doğru } \\
\text { bulmuyorum. }\end{array}$ & $2(\% 4)$ & $2(\% 4)$ \\
\hline Toplam & $50(\% 100)$ & $50(\% 100)$ \\
\hline
\end{tabular}

Tablo 10. "Florun diş̧ çürümelerini önlemek, var olan dişs çürüklerinin ise ilerlemesini durdurmak için koruyucu diş tedavisi olarak diş hekimi tarafindan çocuklarınızın dişlerine uygulanması konusunda ne düşünüyorsunuz?" sorusuna verilen yanıtların yüzde dağııımı

\begin{tabular}{|l|c|c|}
\hline & $\begin{array}{c}\text { Anket I } \\
(\mathbf{n}, \%)\end{array}$ & $\begin{array}{c}\text { Anket II } \\
(\mathbf{n}, \%)\end{array}$ \\
\hline $\begin{array}{l}\text { Diş hekimi uygun görüyorsa } \\
\text { kesinlikle uygulanabilir. }\end{array}$ & $37(\% 74)$ & $44(\% 88)$ \\
\hline $\begin{array}{l}\text { Uygulanması gereken bir } \\
\text { tedavi olduğundan } \\
\text { şüpheliyim. }\end{array}$ & $8(\% 16)$ & $4(\% 8)$ \\
\hline $\begin{array}{l}\text { Uygulanmamasının daha doğru } \\
\text { olduğunu düşünüyorum. }\end{array}$ & $3(\% 6)$ & $1(\% 2)$ \\
\hline $\begin{array}{l}\text { Kesinlikle uygulanmasını } \\
\text { istemiyorum. }\end{array}$ & $2(\% 4)$ & $1(\% 2)$ \\
\hline Toplam & $50(\% 100)$ & $50(\% 100)$ \\
\hline
\end{tabular}

Tablo 11. "Flor içeren diş macunlarının zeka geriliği veya otizme sebep olduğu konusundaki düşüncelere katıllyor musunuz?"sorusuna verilen yanıtların yüzde dağılımı

\begin{tabular}{|l|c|c|}
\hline & $\begin{array}{c}\text { Anket I } \\
(\mathbf{n}, \%)\end{array}$ & $\begin{array}{c}\text { Anket II } \\
(\mathbf{n}, \%)\end{array}$ \\
\hline Kesinlikle katılmıyorum. & $19(\% 38)$ & $33(\% 66)$ \\
\hline Çoğunlukla katılmıyorum. & $12(\% 24)$ & $9(\% 18)$ \\
\hline Kısmen katılıyorum. & $12(\% 24)$ & $6(\% 12)$ \\
\hline Kesinlikle katılıyorum. & $7(\% 14)$ & $2(\% 4)$ \\
\hline Toplam & $50(\% 100)$ & $50(\% 100)$ \\
\hline
\end{tabular}

Tablo 12. "Diş macunlarının tüplerinin dip kısmında bulunan renklerin diş macunlarının kimyasal içeriği hakkında bilgi verdiği konusundaki düşüncelere katılıyor musunuz?" sorusuna verilen yanıtların yüzde dağılımı

\begin{tabular}{|l|c|c|}
\hline & $\begin{array}{c}\text { Anket I } \\
(\mathbf{n}, \%)\end{array}$ & $\begin{array}{c}\text { Anket II } \\
(\mathbf{n}, \%)\end{array}$ \\
\hline Kesinlikle katılmıyorum. & $6(\% 12)$ & $32(\% 64)$ \\
\hline $\begin{array}{l}\text { Çoğunlukla } \\
\text { katılmıyorum. }\end{array}$ & $13(\% 26)$ & $7(\% 14)$ \\
\hline Kısmen katılıyorum. & $22(\% 4)$ & $7(\% 14)$ \\
\hline Kesinlikle katılıyorum. & $9(\% 18)$ & $4(\% 8)$ \\
\hline Toplam & $50(100)$ & $50(\% 100)$ \\
\hline
\end{tabular}




\section{TARTIŞMA}

Bilgi ve teknoloji çağı ile birlikte insanlar kitle iletişim araçlarını yaygın olarak kullanmaya başlamışlardır. Kitle iletişim araçlarından en yaygın kullanılanı da televizyon ve internettir. Hem geliştirici hem de olumsuz özellikleriyle televizyon günümüzde en yaygın kullanılan medya aracı olarak belirtilmiştir. ${ }^{20}$ Televizyonun bu kadar popüler olması onun birden fazla duyuya aynı anda hitap etmesidir. Yapılan bilimsel araştırmalar sonucunda, Türkiye'de bireylerin televizyon izlenme süresinin günde ortalama 4-5 saat olduğu tespit edilmiştir. Bir birey yılda vaktinin \%19'unu televizyon izleyerek, \%33'ünü uyuyarak, \%33'ünü çalışarak, \%14'ünü de farklı aktivitelerle geçirmektedir. Bu sonuçlar bize yapılması gereken zorunlu aktiviteler dışında bireylerin kalan zamanını televizyon karşısında harcadığı anlamına gelmektedir. ${ }^{20}$ Bununla birlikte iletişim araçları özellikle de televizyon aracılığıyla bireylerin bilinçsiz bir şekilde ve önemli oranda yönlendirilmeye açık oldukları; çoğu kez okudukları ya da izledikleri haberleri sorgulama intiyacı duymadan inandıkları aşikardır. ${ }^{21}$

Kitle iletişim araçlarının temel işlevi insanlar için bilgi, eğitim ve öğretim sağlamanın yanı sıra eğlenceyi de sağlamaktır. Kitle iletişim araçları bir ülkenin karşı karşıya olduğu birçok kamu hizmetini ve diğer sosyal sorunları ele alma çabalarında potansiyel olarak güçlü bir araçtır. ${ }^{22}$

Halk sağlığı profesyonelleri, sağlık tutumlarını ve davranışlarını şekillendirmek için bir araç olarak televizyonun ve diğer kitle iletişim araçlarının amaçlı kullanımını araştırmaya başlamıştır. ${ }^{23}$ Bununla birlikte, kitle iletişim araçlarının tutum ve davranışları etkilemek için kullanabilme olasılığı uzun süredir tartışılmaktadır. Kitle iletişim araçları faydalı bilgiler vermenin yanı sıra, zaman zaman konusunda uzman olmayan kişiler tarafından verilen demeçler sonucunda sağlık konusunda kafa karışıklıkları yaşayabilmektedirler.

Kişilerin iletişim araçlarında yer alan sağlık konulu haber ve yazılardaki bilgilere olan güvenme seviyelerini ölçümlemenin amaçlandığı ülkemizde yapılan bir çalışmada, gazetedeki bilgilere "her zaman" ve "çoğunlukla"güvendiklerini söyleyenlerin oranı \%27 iken, bu oran internette \%36, televizyonda ise \%40 olarak tespit edilmiştir. Aynı çalışmada, gazete içeriklerine "kısmen" ya da "nadiren" güvenenlerin oranı $\% 66$ iken, internette $\% 59$, televizyonda ise \%54 düzeyinde olduğu belirtilmiştir. "Hiçbir zaman güvenmem." diyenlerin oranı ise, gazete için $\% 7$, televizyon için $\% 6$ ve internet için ise \%5 olarak belirtilmiştir. Medya içeriklerine yönelik değerlendirmeler bağlamında kamuoyu anketine katılan vatandaşlara ayrıca "Sağlık konulu içerikler (Gazete/ televizyon/ internetteki) sayesinde tıp doktorlarına olan güvenim azaldı." ifadesi hakkında fikirleri sorulmuştur. Alınan cevaplar değerlendirildiğinde ise yaklaşık olarak her 10 kişiden biri medya içerikleri sayesinde tıp doktorlarına olan güvenlerinin azaldığını belirtmiştir. ${ }^{24}$ Yaptığımız çalışmadan elde ettiğimiz verilerde ise ilk anketle ikinci ankete verilen cevapları karşılaştırdığımızda, sonuçlar bu bilgileri destekler niteliktedir. Katılımcılar \%48 çoğunlukla günlük 1-3 saatlerini haberleşme ve iletişim araçlarına ayırdıklarını, güncel konular hakkındaki bilgileri \%24 çoğunlukla internet (sosyal medyadan) elde ettiklerini, haberleşme ve iletişim araçlarını \%35 çoğunlukla kısmen güvenilir bulduklarını belirtmişlerdir. Yapılan ilk ankette flor ve diş macunu ile ilgili sorulara verilen cevapların yüzdelikleri ile bilgilendirme sunumundan sonra verilen cevapların yüzdeliği karşılaştırıldığında ise ilk ankete kıyasla doğru cevaplar en çok yüzdeliğe sahip olmuştur.

Çalışmamızdan elde ettiğimiz verilerin sonucunda; bireylerin yazılı ve görsel medyadan etkilenme durumunun yüksek olduğu tespit edilmiştir. $\mathrm{Bu}$ durum bireylerin yaşantısını etkileyecek sağlıkla ilgili haberlerin denetimsiz yayımlanmasının olumsuz sonuçları olabildiğini ortaya koymuştur. Yüksel ve ark. bu konuya ilişkin yaptıkları çalışmada; sağlık yayınlarını kimin yapması gerektiği ve bu kişilerin nasıl bir eğitim alması gerektiğine ilişkin sorular yöneltmişlerdir. Sorulara verilen yanıtlara bakıldığında; "Habercilere temel sağlık eğitimi ya da kursu sertifikası gibi hizmet içi eğitim verilmesi", "Uzman sağılk muhabiri/ editörü olmalı", "İletişim fakültelerinde sağlık haberciliği dersi verilmeli", "İletişim fakültesi/ Gazetecilik mezunu olmalı" gibi medyada yayımlanan haberlerde uzman denetiminin şart olduğunu gösteren görüşler ortaya konulmuştur. Sağlık profesyonellerinden alınan tavsiyeler de ise; sağlık programı yönetmenlerinin tıp doktoru olması ya da sağlık haberlerinin sağlık alanında yetişmiş bireyler tarafından değerlendirilmesi gerektiği yönündedir. ${ }^{24}$

\section{SONUÇLAR}

$\mathrm{Bu}$ çalışmanın verileri ışığında, diş hekimliğinde medyanın toplumun doğru medya ile ilgili sağlık haberleri, yetkili kurumlar ve bu konuda otorite olan kişiler tarafından denetlenmesi gerekmektedir. Ancak 
bu şekilde medya toplumun bilinçlendirilmesi için etkili bir araç olarak kullanılabilir.

NOT: Çalışmada herhangi bir yazar, kurum ya da kurulus ile çıkar çatışması içerisinde bulunmamaktadır. Makale daha önce hiçbir yerde yayınlanmamış ve yayınlanmak ïzere işlem görmemektedir

\section{KAYNAKLAR}

1.Locksley G. The media and development: what's the story?: The World Bank; 2009.Paper no:158. https://openknowledge.worldbank.org/handle/109 86/5924 License: CC BY 3.0 IGO.

2.Kocadaş B. Kültür ve medya. Uluslararası İnsan Bil Derg 2005;34:1-13.

3.Iversen AC, Kraft P. Does socio-economic status and health consciousness influence how women respond to health related messages in media? Health Educ Res. 2006;21:601-10.

4.Mendi B. Sağlık iletişiminde sosyal medyanın kullanımı: Dünyadaki ve Türkiye'deki uygulamalar. Marmara Üni. Öneri Derg. 2015; 11: 275-90.

5.Sebastian ST, Sunitha S. A cross-sectional study to assess the intelligence quotient (IQ) of school going children aged $10-12$ years in villages of Mysore district, India with different fluoride levels. J Indian Soc Pedod and Prev Dent. 2015;33:30711.

6.Kundu H, Basavaraj P, Singla A, Gupta R, Singh K, Jain $S$. Effect of fluoride in drinking water on children's intelligence in high and low fluoride areas of Delhi. J Indian Assoc Public Health Dent. 2015;13:116-21.

7.Wang S-X, Wang Z-H, Cheng X-T, Li J, Sang Z-P, Zhang $X-D$, et al. Arsenic and fluoride exposure in drinking water: children's IQ and growth in Shanyin county, Shanxi province, China. Environ Health Perspect. 2007;115:643-7.

8.Trivedi M, Verma R, Chinoy N, Patel R, Sathawara N. Effect of high fluoride water on intelligence of school children in India. Fluoride. 2007;40:178-83.

9.Lu Y, Sun Z, Wu L, Wang X, Lu W, Liu S. Effect of high-fluoride water on intelligence in children. Fluoride. 2000;33:74-8.

10.Seraj B, Shahrabi M, Shadfar M, Ahmadi R, Fallahzadeh $M$, Eslamlu $H F$, et al. Effect of high water fluoride concentration on the intellectual development of children in makoo/iran. J Dent (Tehran, Iran). 2012;9:221-9.

11.Küçükeşmen Ç, Sönmez H. Dişhekimliğinde florun, insan vücudu ve dişler üzerindeki etkilerinin değerlendirilmesi. SDÜ Tıp Fak Derg, 2008; 15: 4353.

12. 20 Ekim 2016 Basın Bülteni, http://www.tdb.org.tr/tdb/v2/ekler/TDB_Flor\%20B as\%C4\%B1n\%20B\%C3\%BClteni_20.10.2016.pdf.

13. Eğri $M$, Çetinkaya F. Diş Hekimleri ve Flor Kullanımı. Turgut Özal Tıp Merkezi Dergisi. 1998;5:60-3.

14.Ulusoy Y. Pedodontide Güncel Koruyucu Yaklaşımlar. Atatürk Üniv Diş Hek Fak Derg, 2010; Suppl.3: 28-37.

15.Poul Erik Petersen and Hiroshi Ogawa. Prevention of dental caries through the use of fluoride. The WHO approach. Community Dental Health 2016; 33: 66-8.

16.The Reference Manual of Pediatric Dentistry. Policy on Use of Fluoride. Review Council Council on Clinical Affairs Latest Revision 2018:55-6.

17. Guidelines on the use of fluoride in children: an EAPD policy document. Eur Arch Paediatr Dent 2009;10:129-35.

18. Adopted by the FDI General Assembly: August 2017, Madrid, Spain. Promoting oral health through fluoride. Int Dent J 2018;68: 16-17.

19.Ercan E, Baglar S, Colak H. Diş hekimliğinde topikal florür uygulama metotları. Cumhuriyet Dent J. 2010;13:27-33

20.Altun A. Türkiye'de medya okuryazarlığı. İlköğretmen Eğitimci Dergisi. 2008;16:30-4.

21.Korkmaz Ö, Yeşil R. Medya ve televizyon okuryazarlık düzeyleri ölçeği geçerlilik ve güvenirlik çalışması. Uluslararası İnsan Bilimleri Dergisi. 2011;8:110-26.

22. Naveena N. Importance of Mass Media in Communicating Health Messages: An Analysis. IOSR- Journal of Humanities and Social Science. 2015;20:36-41.

23.Warner KE. Television and health education: stay tuned. APHA; 1987; 77:140-2.

24. Yüksel E, Kaya A, Koçak A, Aydın S. Türkiye'de Sağlık Konulu Yayıncılık İlkelerinin Belirlenmesi: Kaynak. İleti ve Hedef Kitle Bağlamında Sağlık Konulu Yayınların Analizi 109K534 nolu Basılmamış TÜBİTAK Proje Raporu. 2013.

\section{Yazışma Adresi}

Doç.Dr. Sera Şimşek Derelioğlu

Atatürk Üniversitesi, Diş Hekimliği Fakültesi

Pedodonti AD, Erzurum/TÜRKİYE

e-mail: simseksera@gmail.com 